\title{
海底磁力計による地震予知の提案*
}

\author{
東京都立雪谷高等学校 宮 本 貞 夫 \\ (昭和 40 年 1 月 18 日受理)
}

\section{A Proposal of Plan of Predicting Earthquakes \\ by the Marine-magnetometer.}

\author{
Sadao Miчамото \\ Yukigaya High School, Tokyo \\ (Received Jan. 18, 1965)
}

A plan of the marine-magnetometer was made public in September, 1964 at the meeting of the Society of Terrestrial Magnetism and Electricity of Japan.

The writer proposes that about twenty marine-magnetometers for the total force are necessary for the predicting of earthquake.

If the marine-magnetometer consists of three elements, constructing twenty stations may be economically impossible within five years.

But if the magnetometer is constructed of only one element, which is the total force, twenty stations may be possible, because the structure is very simple.

An optical-pumping magnetometer is most suitable for the marine-magnetometer, because this magnetometer can record such a quick change as $500 \mathrm{c} / \mathrm{s}$, and perfectly continuously.

This magnetometer is much more sensitive and much smaller and remote-recording is much more suitable than any other magnetometer. The consumption of the electric power of this magnetometer is very little and shake-proof, because this was invented for the magnetometer of the rocket in 1957 in USA.

\section{$\S 1$. 計 画}

地球電磁気学会が昭和 39 年 9 月に地球電気磁気学研究将来計画と題する印刷物で公表した 所によると太平洋各地の海底に磁力計を固定し遭続観測をする計画を重要な項目として発表し ている. 初めの 3 年間は機械の開発で, 次の 2 年間で製作し, それ以後に観測所設置 ${ }^{11}$ に移る. プロトンおよび光ポンピング磁力計の予定である.

実は昭和 38 年春の同学会で将来計画について討論のあつたとき, 鉄道電化により陸上観測 点に制約の大になることが討議されたとき，筆者は将来計画の中に研究的にでも海底磁力計の 研究開発の必要ありと主張したが，そのときは海底磁力計の開発はまだ考えていないとの回答 を担当者が答え，だが永田武博士はその開発を促したが，それ以上にその案は進展しなかつた が，翌年に発表された将来計画では海底磁力計の開発が重要項目としてとり上げられて筆者は

\footnotetext{
* 昭和 40 年 5 月 8 日地震学会で発表.
} 
非常に満足している.

この目的は地球全体の地磁気観測にあつて，特定の一局部の地磁気観測にあるのではない。 陸上では分布に制限があつて全体を知るために広く太平洋各地の海底に分布する目的である.

\section{$\S 2$ ． 筆者の構想}

しかし日本附近の海底に設置するときは, 三陸沖や南海道沖などの大地震の起こる公算の大 なる地域にも設備すれば，大地震と地磁気変化の関係を検討する資料が得られる可能性があ る. 海底地震計も同一点に設備すれば，振 動との関係も明らかになり有効であると考えられ る、電波による遠隔記録を行なうはずだから，両者が共通に用いられる浮遊物を用いれば経済 的であるはずである，風向，風速なども同時に行な光ば，台風進路推定に役立つ地点も生ずる はずであり，国家的事業としてさらに大きい協力が得られるのではないかと思われる。

地震学会と地球電磁気学会が協力して将来はこの研究が行なわれることを期待する.

地震予知計画研究グループおよび地震予知部会の各位が地球電気磁気学の将来計画の関係者 に対し積極的な連絡が行なわれることを筆者は希望するものである.

海底地震計と海底磁力計も陸上で遠隔記録するのに別々に研究していたのでは非経済的と思 われる点がある，日本近海に設置する地点について両学会のそれぞれの見地を総合して合理的 な結論を導くのも必要かと思わ秃る。

\section{§3． 海底磁力計に適する磁力計}

棒磁石を吊した型式は不適当である.プロトンまたは光ポンピング磁力計が適当である．特 に海底用としては後者がすぐれている.

前者は消費電力が大きいが，後者の消費電力は小さい. 前者は断続的観測だが，後者は完全に連続的観測である. 後者は前者より変化量を 1 桁程度感度を高く記録できる。

1957 年に米国で初めて論文に公表された所の光ポンピング磁力計はルビジウムの光を用い ルビジウム原子を励起し，磁場によるその原子のゼーマン效果を利用するものである.

$\mathrm{Rb}$ 原子を磁場の中に入れるとそのエネルギーは変化し数本の副準位に分離する．このゼ一 マン効果によつて分離したエネルギーは磁場の強さに比例する．副準位間を遷移するとき，原 子が吸収または放出する電磁波の周波数は磁場の強さに比例する. AFC 方式, 原子発振方式, 共鳴変調方式2などがある．原子発振方式が主に用いられている．ロケットによる宇宙空間の 磁場測定用に米国で開発されたもので, 検出部は約 $1 \mathrm{~kg}$, 増幅器は約 $0.5 \mathrm{~kg}$ の小型軽量で高 精度で絶対值の連続観測できる特性をもつすぐれたものである．振 動にも耐え得る．精度は 
$\pm 1 \gamma$ でしかも数 $100 \mathrm{c} / \mathrm{s}$ (原子発振方式のとき)の早い变化も連続記録できるのである. 変化 量の測定はプロトン磁力計より，約 1 妳感度が高い.（光ポンピング磁力計は航空機用として もプロトン磁力計よりすぐれていると考えられる，消費電力が小さい．傾斜や振動による影響 をうけない)。

この磁力計は日本では 1963 年より日本電気 K. K. 通信技術研究所の光電磁気研究室 ${ }^{3}$ にて 研究試作し, ロケットに原子発振方式のものが塔載され 1964 年秋に東北大学と共同公表を地 球電磁気学会でされた。別に小川 徹 (同志社大学工学部) が研究し, 共鳴変調の新方式を試 作公表している. (三菱電気 K. K. 中央研究所製作)

地球電磁気学会の将来計画の測器部門の担当者は昭和 38 年の将来計画の討論会で光ポンピ ング磁力計を次の重要な磁力計と考え, 将来は陸上でも海底でも主要な磁力計になるはずであ るとの意味を公表したと筆者は了解している.

しかし現在はまだ光ポンピング磁力計は十分には理解されていない段階である.

\section{§4. 広範囲の測量}

地震予知の目的からは観測点が少ない欠点を補らため, 船船㐨よびヘリコプター，飛行機な ぞの航空磁気測量も必要と思う。

東北大学の加藤愛雄博士が昭和 39 年 2 月 7 日より 3 月 3 日の 26 日間にわたり, 箱根, 十和田湖, 鬼首カルデラの三火山をへリコプターで約 $100 \mathrm{~km} / \mathrm{h}$ の速度, $4,000 \sim 5,000 \mathrm{ft}$. と $5,000 \sim 6,000 \mathrm{ft}$. の 2 つ高度面でプロトン磁力計で $5 \mathrm{sec}$ 間隔の測定の記録をしたが想像 以上の高い精度であつた。 $5 \gamma$ 以下の誤差で位置も $\pm 10 \mathrm{~m}$ 以下の誤差であると公表された.

Fig. 5 のごとく精密な磁気異常図が公表された。将来において光ポンピング磁力計が利用 されるならば，さらに精度の向上することは明らかである。

地球電気磁気学の将来計画の印刷物によると, 航空 機, ヘリコプター, 外航船船も記入さ れ，500 万円の航空磁気儀 2 台，500 万円の光ポンピング磁力計 8 台が予定されている.

5 力年計画が実行されれば，新鋭の磁力計で航空，海上磁気測量が広範囲に行なわれること に地震予知に関心を持つ人々も注意する必要があると思う。これをくりかえしまた固定点の海 底磁力計の運続記録の資料が総合的に検討されることは有意義と考元る.

\section{$\S$ 5. 筆者の提案（全磁力を測定せよ）}

地磁気の三成分観測を将来計画では原則としているが，各成分の観測には直径約 $2 \mathrm{~m}$ の ルムホルッコイルが必要でかつ方向性が正確に要求されるので海底用としては相当に研究課題 
がある.地震予知の目的には全磁力だけを簡単に多数点で測れば良いわけである。

将来計画の三成分のもの以外に全磁力のものを少なくとも 20 点位海底に設置すれば， 3 地 点のみに比較すれば本来の目的および地震予知の目的に有效な資料がより效果的に得られるは ずである.

註 1) 将来計画の印刷物の一部を示す.
(A) 海洋地磁気観測所
海洋地磁気観測所
8,000 万円
海洋地磁気検出器 (3 成分, 海底に固定)
$3,000 \times 3=9,000$ 万円
水中通信器
$3,000 \times 3=9,000$ 万円
小 計 2 億 6,000 万円
(B) 海洋地磁気観測所の人員 6 人

（ 5 年計画ではわずかに 3 地点に海底磁力計が設置されるにすぎない，さらにその後に太平洋の海底 の各地点に多く設備されるものと思われる.)

(C) 地磁気測定器の近代化

開発研究並びに機械製作は既設各機関で分担する，したがつて特別な施設は不要

常設地磁気観測所

絶対観測機械 3,000 万円 $\times 2$ セット $\times 3$ 地点 $=1.8$ 億円

変化観測機械 3,000 万円 $\times 2$ セット $\times 3$ 地点 $=1.8$ 億円

その他の地磁気観測所

地 磁 気測定器 5,000 万円 $\times 4=2.0$ 億円

ディジタル記録器 3,000 万円 $\times 3=0.9$ 億円

地磁気測量機械 2,000 万円 $\times 10=2.0$ 億円

小 計 8 億 5,000 万円

註 2）高周波磁場の制御の方法で 3 方式に分れる。

AFC 方式…(Automatic Frequency Control System あまり用いられていない.)

静磁場に微小低周波磁場を重畳させ，ルビジウムガスの共鳴周波数を低周波で变調し，高周波発振器 の発振周波数を制御するもの. 不均一磁場内で十分に作動する利点はあるが，測定周波数が数 $10 \mathrm{c} / \mathrm{s}$ 以下の欠点のため今はあまり用いられていない。

原子発振方式…(回路が簡単でこの方式が主に用いられている.)

自励発振方式ともいう． $\mathrm{Rb}$ 原子の共鳴周波数で磁気共鳴を起こしている $\mathrm{Rb}$ ガスを通過した $\mathrm{Rb}$ ラ ンプからの光が変調されるので, この光の検波出力を磁気共鳴を起こさせるための高周波コイルに帰 還して系全体を発振器とするもの.

速い磁場（数 $100 \mathrm{c} / \mathrm{s}$ ）の变動孔測定可能 Fig. 1 飞系統図を示す.

Fig. 2 は検出部の外観，Fig. 3 はその記銶を示す，日本電気 K. K. がロケット塔載用に製作したも のである.

共鳴変調方式

不均一磁場内でも測定可能であり, 数 $100 \mathrm{c} / \mathrm{s}$ の速い磁場変化も測定可能である．静磁場に交流磁場 を重置させ，交流磁場の周波数を適当に選び大きく共鳴することを利用する，これは一般にはあまり 知られていない。これは小川 徹の着想によるものである。 
系統図は Fig. 4 亿示す。変調周波数之共鳴周波数が等しいので高周波コイルによる交流磁場は変調 と共鳴を同時に起こさせる。ルビジュームランプからの光は高周波コイルにより共鳴陂調され，光電管 に達し検波される。光電管の出力学位相娭波器に入れてこの出力で高周波 発振器の周波数㕝制御すれ ば，磁力計として作動させることができる。

一般的に比較すると従来の磁力計では測定不可能で步つた時間的に早い变化が連続観測可能であるこ とに注目すべきであると思う。

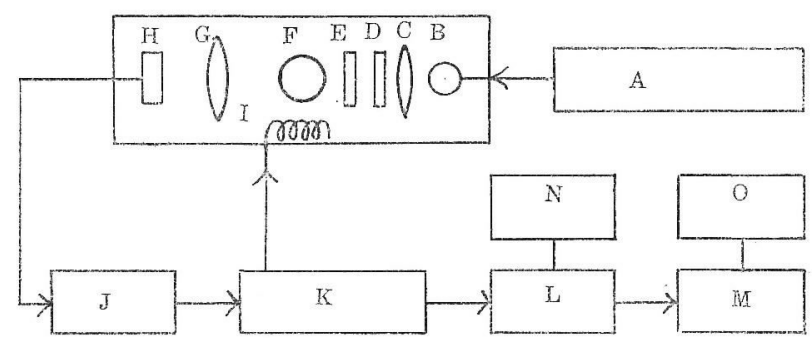

Fig. 1 Optical pumping magnetometer (Self oscillating system)
A RF Exciter
I RF coil
B $\mathrm{Rb}$ lamp
J Phase shifter
C Lens
$\mathrm{K}$ RF amp.
D Interference filter
L Mixer
E Polaloid
M Rate-meter
F Rb-cell
$N$ Cristal oscillater
$G$ Lens
O Pen-recorder
$\mathrm{H}$ Photo-cel1

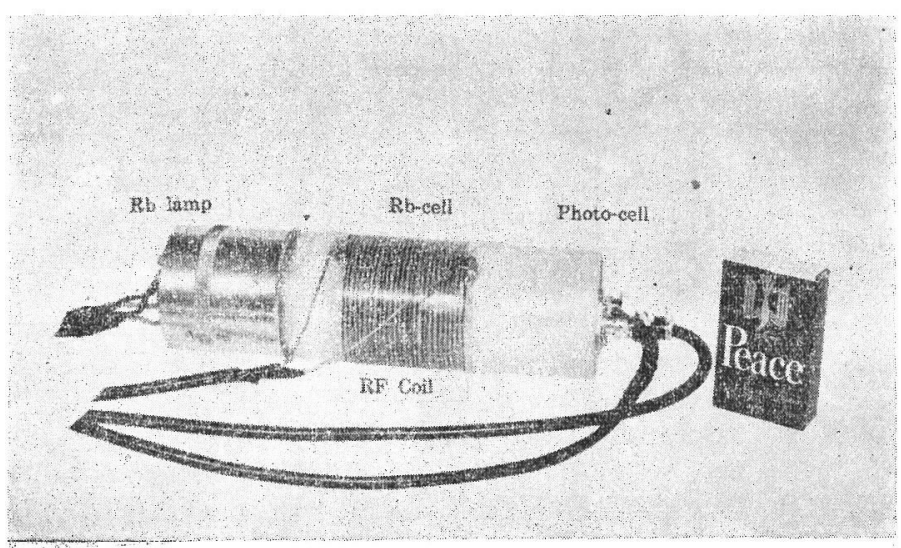

Fig. $2 \mathrm{Rb}$ pumping magnetometer

(Self oscillating system) 


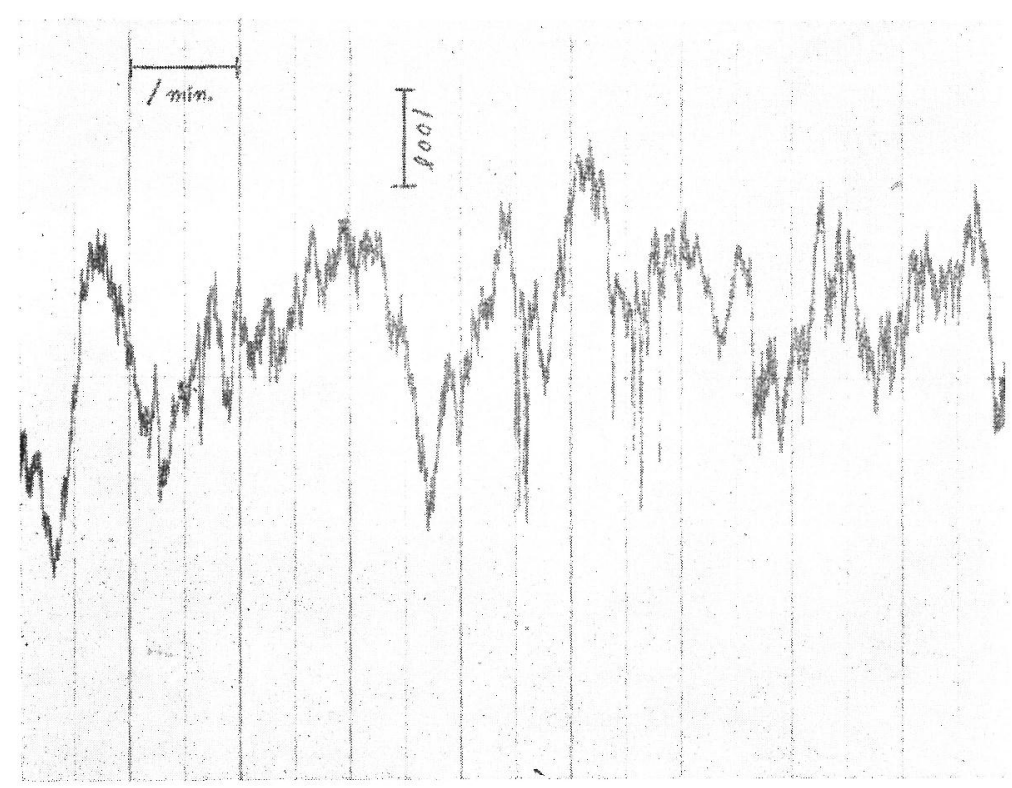

Fig. 3 Record of the $\mathrm{Rb}$ pumping magnetometer

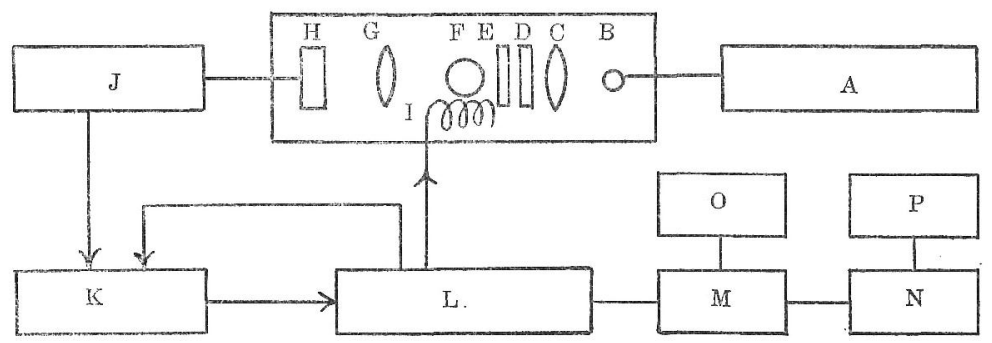

Fig. 4 Optical pumping magnetometer (Resonance modulation system) by $\mathrm{T}$. Ogawa
A RF Exciter
B $\mathrm{Rb}$ lamp
C Lens
D Interference filter
E Polaloid
F Rb-cell
G Lens
H Phto-cell

I RF Coil

J RF Amp.

K Phase sensitive detecter

L RF Oscillater

M Mixer

$\mathrm{N}$ Rate meter

O Critical Oscillater

$P$ Pen recorder 
Aeromagnetic survey over the Towada caldera by the proton precession magnetometer

$$
\begin{array}{ll}
\text { Component: } & \text { Total intensity } \\
\text { Unit } & : \text { Gamma } \\
\text { Height } \quad: & 4000 \mathrm{ft}
\end{array}
$$

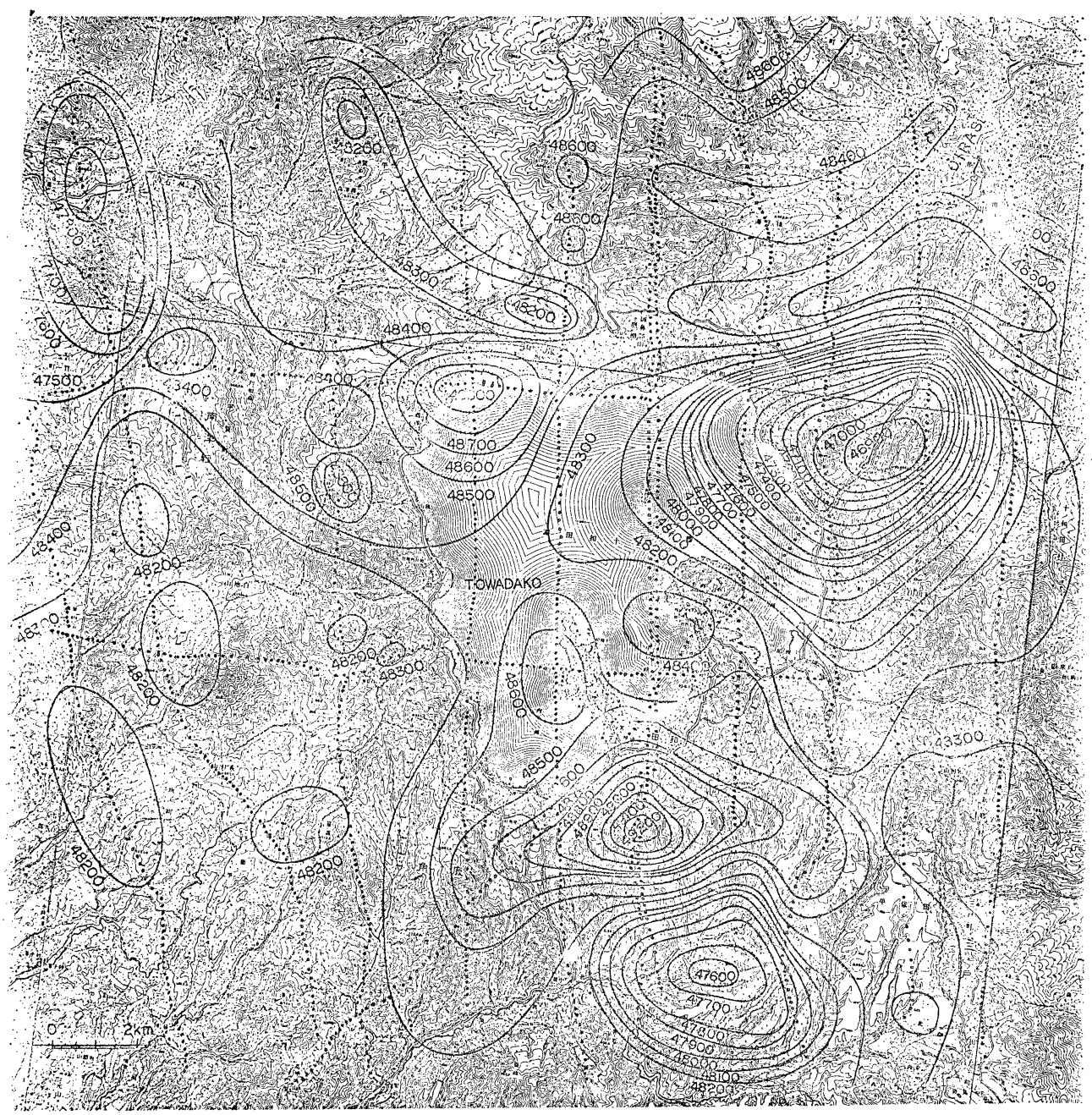

Fig. 5 Geophysical institute of Tohoku University, Sendai. Japan

普通は全磁力を測定するが，ヘルムホルツコイルを用いれば各成分の測定が可能である．絶対值測定 はプロトン磁力計も光ポンピング磁力計も大体同じ精度であるが，変化量の測定は光ポンピング磁力計 の方が 1 桁程度感度が良い.

註 3) 室長代理 宮坂 宗次 室員 佐分利昭夫 - 田中 久夫 